\title{
Young People and Youth Justice
}




\section{Young People and Youth Justice}

Kevin Haines

and

Mark Drakeford 
(C) Kevin Haines and Mark Drakeford 1998

All rights reserved. No reproduction, copy or transmission of this publication may be made without written permission.

No paragraph of this publication may be reproduced, copied or transmitted save with written permission or in accordance with the provisions of the Copyright, Designs and Patents Act 1988, or under the terms of any licence permitting limited copying issued by the Copyright Licensing Agency, 90 Tottenham Court Road, London W1P 9HE.

Any person who does any unauthorised act in relation to this publication may be liable to criminal prosecution and civil claims for damages.

The authors have asserted their rights to be identified as the authors of this work in accordance with the Copyright, Designs and Patents Act 1988.

First published 1998 by

MACMILLAN PRESS LTD

Houndmills, Basingstoke, Hampshire RG21 6XS

and London

Companies and representatives throughout the world

ISBN 978-0-333-68760-4

ISBN 978-1-349-14388-7 (eBook)

DOI 10.1007/978-1-349-14388-7

A catalogue record for this book is available

from the British Library.

This book is printed on paper suitable for recycling and made from fully managed and sustained forest sources.

$\begin{array}{llllllllll}10 & 9 & 8 & 7 & 6 & 5 & 4 & 3 & 2 & 1\end{array}$

$\begin{array}{llllllllll}07 & 06 & 05 & 04 & 03 & 02 & 01 & 00 & 99 & 98\end{array}$ 


\section{Contents}

List of Tables and Figures viii

Acknowledgements $\mathrm{x}$

Introduction: Young People and Youth Justice xii

1 Youth and Society 1

Attitudes Die Hard 3

Young People Today 4

Real Change: For Worse, Not Better 6

Youth Transitions 14

Young People in Trouble 16

$\begin{array}{ll}\text { Conclusion } & 29\end{array}$

2 Juvenile Justice: a Recent History 32

Setting the Scene $\quad 32$

Making Youth Justice Policy Today 34

The Welfare of the Child 35

Intermediate Treatment $\quad 37$

Intended and Unintended Consequences 40

The Origins of Juvenile Justice in the 1980s 43

The Back-to-Justice Movement 44

Systems Management and the Anti-custody

Orthodoxy 47

The Juvenile Justice 'New Orthodoxy' 50

Corporatism? 53

Practitioner-led Change $\quad 55$

Working with Conflict $\quad 56$

An Anti-custody Orthodoxy $\quad 57$

Committed to Systems Management 60

Problems and Pitfalls of Juvenile Justice in the 1980s 61 
3 Developing a Youth Justice Philosophy 68

What do we Mean by Philosophy? 68

Why is Philosophy Important? 70

The Philosophy of Juvenile Justice in the 1980s 73

The Philosophy of the CJA 1991

The Philosophy of Government - Local Implementation $\quad 79$

The Philosophy of Local Agency Managers 82

More Recent Philosophical Changes shaping

Government Criminal Justice Policy $\quad 83$

Politics, Philosophy and Policy 85

A Philosophy of Youth Crime $\quad 87$

A Children-First Philosophy $\quad 89$

Putting Children First in the Youth Justice System 90

Putting Children First in Systems Management 93

4 Managing Youth Justice Systems 99

At the Police Station $\quad 99$

Appropriate Adults $\quad 100$

Police Bail 104

Pre-court Diversion $\quad 105$

Bail Decisions $\quad 111$

Remand 117

Pre-sentence Reports (PSR) 124

Supervision and Breach 130

Custody 134

5 Managing Other Significant Systems 141

Youth Justice and Other Welfare Systems: Four

Shaping a Systems Approach for Today 146

Basic Principles 147

Parental Responsibility $\quad 150$

Income $\quad 154$

Housing 158

Education 161

Employment and Training $\quad 165$

Health 170

Drugs and Alcohol 170

Sex 173

Mental Health $\quad 175$

$\begin{array}{ll}\text { Conclusion } & 178\end{array}$ 
6 Effective Work with Young Offenders 179

The Need for Effective Youth Justice Practice 179

Criminal Careers Research and Early Intervention 182

Methodological Problems 184

Problems of Interpretation 186

The Social Context of Offending 187

Boot Camps and the Institutional Treatment of Children

The Community-based Treatment of Offenders and Issues of Effectiveness

Establishing Community Ties and the Importance of Social Situations

Meta-analysis: lessons for practice 200

Institutionally-based Treatment Programmes 202

Reconciling Institutional and Community-based

Programmes?

What Might Effective Community-based Programmes of Offender Intervention Look Like?

7 Some Contemporary Concerns

209

National Standards and Management Control 209

Risk Assessment

216

Young People and Restorative Justice

229

Young People and Criminal Responsibility

234

Conclusion

Notes

Bibliography $\quad 247$

Index 


\section{List of Tables and Figures}

\section{Tables}

2.1 Justice vs welfare

2.2 Aims of IT identified in interviews with social services departments

2.3 Typology of IT policy in social services departments

2.4 Schema of IT programmes

3.1 The influence of the anti-custody philosophy on the actions of juvenile justice workers at key decision-making points in the juvenile justice system

3.2 Principles of a children-first youth justice philosophy

5.1 Permanent exclusion rates in England

5.2 Reasons for the increase in exclusions

5.3 NHS psychiatric admissions in England and Wales

6.1 Categories of normative treatment

6.2 Average recidivism rates for reintegrative programme participants and non-participants

6.3 A synopsis of the characteristics of effective community-based offender intervention programmes

\section{Figures}

2.1 Selected sentencing trends: percentage of males aged 14-16 found guilty of indictable offences $1970-80$ 
2.2 Selected sentencing trends: percentage of males aged 14-16 found guilty of indictable offences 1980-90

2.3 Males cautioned as a percentage of those found guilty for indictable offences 1980-90

6.1 Dynamic theoretical model of crime, deviance and informal social control over the life-course 


\section{Acknowledgements}

All books are the product of far more than their authors and this is no exception. Our particular thanks are due to those who have helped us along the way by reading and commenting on earlier drafts. Brian Littlechild and Denis Jones were both especially helpful in making positive suggestions for amendments and improvements. We think the book has benefitted from their suggestions and hope they will too. Catherine Gray of Macmillan has provided a steady mixture of encouragement and guidance on the disciplines which meeting deadlines and responding to comments require.

The contents of this book and our deeply held views about the issues it addresses arise from the direct contact we both have with youth justice practitioners and the young people they work with. More than anything else their contribution should stand in these acknowledgements.

Finally to thank our families for the pressure which they absorb and the impetus they provide in bringing such a book to fruition. The long passage from proposal to final manuscript is one which has its inevitable difficulties and families bear the brunt of this - we remain very grateful for their support. The views expressed in this text, and the arguments it contains, are, of course, our own responsibility.

\section{KEVIN HAINES MARK DRAKEFORD}

The authors and publishers are grateful to the following for permission to reproduce copyright material: Department of Health, for Tables 2.2 and 2.3; Carol Hayden for Table 5.1; Children's Legal Centre for Table 5.2; NCH Action for Children for Table 5.3; Figure 6.1 is reprinted by permission of the publisher from 
Crime in the Making: Pathways and Turning Points through Life by Robert J. Sampson and H. Laub, Cambridge, Mass.: Harvard University Press, Copyright (C) 1993 by the President and Fellows of Harvard College. Every effort has been made to contact all the copyright-letter, but if any have been inadvertently omitted the publishers will be pleased to make the necessary arrangement at the earliest opportunity. 


\section{Introduction: Young People and Youth Justice}

This is a book about working with young people and the youth justice system, but it differs in approach from more traditional treatments of this topic. It does not set out, in any systematic way, to review the literature on juvenile and youth justice; nor does it aim to provide a comprehensive synthesis of the 'what works' research. The arguments set out do not rely on detailed discussion of a limited number of projects, undertaken in the hope of discovering some generalisable ideas. This book is, however, rooted in research and what is known about children in trouble and the social systems that surround them. It is about applying accumulated knowledge to the operation of the youth justice system and to work with young people.

The central theme of the book is that there is much to be learned from the successes of recent juvenile justice practice, but that it is important for youth justice to continue developing in ways which meet the changing challenges faced by and presented by young people in our society. To meet these challenges this book proposes that youth justice workers develop practices in line with a philosophy of putting children first.

A Children-First philosophy embraces much from previous juvenile justice practice. Putting children first must still mean that youth justice workers should aim to maximise diversion from the formal criminal justice system, doing all that they can to avoid custody for young people - indeed the children-first philosophy requires re-invigorated efforts aimed at the abolition of custody for children in the light of expansionist custodial penalties for young people aged under 18 years. But such a philosophy goes much further than maximum diversion, minimum custody. 
In a society with increasingly sharp social differentials of wealth and well-being, youth justice practice must adopt a much more proactive strategy towards children generally. Diversion from the criminal justice system must remain an essential systems strategy, but it is no longer justifiable to marginalise children in need, no longer justifiable simply to divert children if diversion means that their lack of access to full-time education, their lack of adequate housing and their other social needs are ignored. Youth justice practice must develop in ways which devise effective methods for supporting children in trouble and difficulty outside the criminal justice system, as well as within it.

Avoiding custody for children must remain a central goal for youth justice practice. But, increasingly, a systems management approach heightens the importance for avoiding custody of a whole series of interventions at other stages of the criminal justice process. An effective Appropriate Adult service and intervention can reduce the chance of an ultimate custodial sentence. Effective bail support programmes are essential for avoiding remands in custody or other closed institutions, and can reduce the likelihood of a custodial sentence. Well-developed community sentences are essential as alternatives to institutional and custodial sentences. The arguments set out in this text remain committed to a systems management approach animated in strategies designed to avoid custodial experiences for children in this respect.

But systems management alone is no longer sufficient. Systems management must be informed by the principles of a Children First philosophy and by knowledge of what effective intervention with children actually means in practice. Keeping children out of the criminal justice system is important, keeping children out of custody is even more important. The rationale which underpins this way of working is based not only on what is best for children themselves, but proceeds from a firm commitment to the better social health of the whole community. Keeping children out of the criminal justice system in general, and its most damaging components in particular, is the best way of ensuring that such individuals do not grow up to be more prolific and more dangerous offenders.

The approach advocated here is one which addresses issues of community safety and crime reduction with every seriousness. In the argument of this book, however, these goals are far less likely to be achieved in a climate which regards them as in competition with, 
rather than arising from, a determination to protect and promote the immediate and longer-term interests of each individual, and children generally. But it is not acceptable to act instrumentally to achieve these objectives if the interests of individuals and children generally are compromised. Youth justice practice must achieve its objectives in ways which are sensitive to the interests of children. This means placing children in their proper social context and distinguishing their behaviour from the responsibilities that others have towards them. Where society, its structures and institutions, fails children this must be made clear. Structured work which aims to integrate not marginalise, which aims to improve the social situation of young people and to maximise their chances both now and in the future, must be the goal.

The Children First philosophy, which is developed in this book, does not involve the mechanical application of routinised procedures to children in difficulty or danger. Effective youth justice practice can only be the product of knowledgeable, thinking and skilled practitioners who set about their work in an adventurous and innovative manner. Consequently one of the main aims of the book is to provide current and prospective youth justice practitioners with the necessary tools to carry out their work in an informed and determined manner. Putting children first does not mean rigid adherence to pre-determined procedures, ticking the boxes of anti-oppressive or anti-discriminatory practice. A ChildrenFirst philosophy means being proactive on behalf of children; it means working hard to educate others to understand more and to dispel the myths about, for example, serious or persistent offenders; it means constantly developing and redeveloping effective systems management strategies and supervision programmes, of reinvigorating appeals against harsh or inappropriate judgements. Above all it means adapting and constantly striving to put children first.

To achieve a Children First approach, youth justice practitioners must have a thorough understanding of the nature and experience of youth, and knowledge about the way society and its social structures treat children. Chapter 1 aims to provide an introduction to this topic and to outline the sorts of knowledge and information that are relevant to understanding children and their social context.

Chapter 2 comprises a more detailed analytical review of juvenile justice. If youth justice in the future is to be able to build on the 
effectiveness of the past then an adequate understanding of that past must be achieved. The aim of Chapter 2, therefore, is to describe that past, to give due recognition to the complex dynamics of, for example, the new orthodoxy of the 1980s, and to highlight the realities of juvenile justice practice and signal the components of a remarkable criminal justice success story. The reason for doing this, however, is not to glory in the past, but to learn from the past to make a success in the future.

People do things for reasons. These reasons may not always be totally explicit, to individuals or others, but they are always there. It is absolutely essential that youth justice practitioners not only know what they are doing but also why they are doing it. Knowledge and skills are important components in this process, but alone they are insufficient; purposeful action is meaningless unless it is given some direction. Understanding the purposes of action, the objectives which action is directed to achieve, can only be realised if we are explicit about matters of philosophy. In this context philosophy is not some abstract theory but an understanding of the principles that motivate individuals to behave in particular ways. Such is the importance that this book attaches to matters of philosophy that the whole of Chapter 3 is devoted to the development of our ideas of a philosophy for contemporary youth justice practice, including putting children first in systems management.

Chapter 4 gets down to more practical matters with an exploration of issues of managing youth justice systems. This chapter is concerned to discuss the principles and practices of criminal justice systems management updating this important topic in the light of an assessment of previous practice and the needs of the future. Seven key points within the youth justice system are identified and the development of effective practice discussed in relation to each one.

Chapter 5 is similarly rooted in systems management, but is innovative in the way it advocates the extension of these techniques to systems outside the criminal justice sphere. Young people live their lives in a range of systems, formal and informal, ranging from family and peers through schools, employment, health, housing and welfare support. Increasingly these systems are becoming hostile to an ever more marginalised youth population; a young and marginalised population whose treatment by other systems, including the criminal justice system, is often more of a negative reaction 
to their 'system status' rather than to them as individuals. Adopting a Children First philosophy necessitates an extension of systems management techniques to maximise the opportunities for children to benefit from all formal and informal systems of support. Chapter 5 discusses the principles and practices of managing these other significant systems.

If direct work with young people is to be effective then it must be based on the research which seeks to produce this specialist knowledge. Chapter 6 turns to the literature on the effects of various interventions on future behaviour, beginning with a brief examination of what does not work, and what does harm. Knowing what does not work, and what not to do, is as important as knowing what does work and how to do it. It is argued consistently in this book that youth justice practice must be about doing good, as well as avoiding harm, but avoiding harm remains a primary duty of any practitioner. Practitioners must develop skills in persuading others that some approaches and some treatments are negative and can do much more harm than good - being well-informed about these matters is, therefore, important. The bulk of this chapter, however, is devoted to a discussion of what is known about effective offender interventions. The research is presented in such a way as to build a model for intervention based around control theory and a normalising principle.

Finally, Chapter 7 takes the opportunity to address in more detail some issues of contemporary importance. These issues are: National Standards, risk-assessment, restorative justice and young people, and criminal responsibility. There are dangers in all these areas, but positive aspects too. This chapter attempts to map out these dangers and to suggest more proactive strategies which will assist youth justice workers to meet emerging challenges. 